\title{
Development and Validation of HPLC Method for the Quantification of Anticancer Peptide
}

\author{
JAGATHEESH KALIYAPERUMAL, PAVANKUMAR PADARTHI \\ KOWSALYA RANGASAMY and ELANGOVAN NAMASIVAYAM*
}

Molecular Pharmacology Research Laboratory, Department of Biotechnology, Periyar University, Salem, Tamilnadu-636011, India

elangovannn@gmail.com

Received 3 January 2014 / Accepted 24 January 2014

\begin{abstract}
As the prevalence of cancer persists, the development of new and more advanced therapies remains a main concern in the health research. In this work the development and validation of HPLC method for the quantification of anticancer peptide were checked for analytical validation parameters were accuracy, precision (repeatability and reproducibility), specificity, sensitivity (limit of detection and limit of quantification) and linearity. The accuracy and precision of the method have been tested and the coefficients of variation have been found to be less than $2 \%$ according to ICH validation guideline. The linearity range was found to be $5-35 \mu \mathrm{g} / \mathrm{mL}$, LOD-5.65 $\mu \mathrm{g} / \mathrm{mL}$ and LOQ$17.1322 \mu \mathrm{g} / \mathrm{mL}$ respectively. In conclusion, a new RP-HPLC method has been developed and validated successfully for the quantitative analysis for the peptide in this study.
\end{abstract}

Keywords: Cancer, RP-HPLC, Quantitative analysis, Peptide, Analytical method

\section{Introduction}

High performance liquid chromatography (HPLC) has developed into a widely used, wellestablished tool for the analysis and refinement of biomolecules. The rationale for the central role that HPLC now plays in analyzing and refining proteins / peptides is resolution HPLC is able to split polypeptides of nearly identical sequences, not only for small peptides such as those obtained through trypsin digestion, but even for much larger proteins. In recent years, significant concentration has been paid to the use of peptides as therapeutic agents and this inclination is expected to continue. Because of their wide-ranging activities in many physiological processes such as acting as signaling molecules and growth factors, peptides play a considerable role as therapeutic mediators, chiefly in the areas of neurology, endocrinology and hematology. Even though peptides have been shown to be promising therapeutics for many disease conditions, developing them as drugs is a challenging process since the accurate quantification of peptides is one of these challenges and their poor stability, losses during manufacturing and delivery process and their high cost are other issues. Incorrect quantification of peptides may lead to false conclusions in research and may also adversely affect the dosage that is prescribed for patients. 
Still nevertheless, discovery of protein and tumor-related peptides and proteins is expected to create a "new wave" of more effective and selective anticancer drugs in the future, capturing the large share of the cancer therapeutic market. It may plays a vital role in next generation cancer therapy. And the peptide $p$-ACC1 designed for tumor suppressor by interaction with BRCT domains ${ }^{1}$. The present work is focused to develop the analytical method and validation of HPLC for quantification of the peptide

\section{Experimental}

The HPLC system of SHIMADZU - UFLC series with Rhodyne injector 77251, Hamilton syringe-25 $\mu \mathrm{L}$ C18G120A column, 250x4.6 mm 5U with guard column WM03-0.22, detector $\mathrm{UV}$ at $220 \mathrm{~nm}$. The chromatographic analyses were carried out at $5{ }^{\circ} \mathrm{C}$ using reversed phase. The peptide was purchased from life technologies. Spectroscopic grade trifloroacetic acid (TFA) and HPLC grade acetonitrile were purchased from Sigma-Aldrich, USA

\section{Methods}

The mobile phase A $1 \% \mathrm{w} / \mathrm{v}$ of triflouro acetic acid in water and Mobile phase B $0.1 \% \mathrm{w} / \mathrm{v}$ of triflouro acetic acid in 80:20 ratio of acetonitrile and water were used. The flow rate was set at $1.0 \mathrm{~mL} / \mathrm{min}$ and the wavelength set as $220 \mathrm{~nm}$. The injection volume was kept as 20 $\mu \mathrm{L}$ and the sample solution was prepared by accurately weighed quantity of peptide sample $5 \mathrm{mg}$ in $5 \mathrm{~mL}$ volumetric flask and dissolved with sufficient water and made the volume up to $5 \mathrm{~mL}$ ultrapure water.

The analytical validation parameters were selected according to the Validation of analytical procedures (Q2, R1) of ICH Harmonised Tripartite Guideline ${ }^{2}$. Analytical validation parameters were accuracy, precision (repeatability and reproducibility) specificity, sensitivity (limit of detection, LOD; limit of quantification, (LOQ) and linearity

\section{Accuracy}

Three different concentrations of samples including high, medium and low concentrations were used for determination of accuracy. Accuracy was expressed as the percentage of coefficient of variation (\% CV). All values found for the three different concentrations of peptide were lower than $2 \%(n=3)$ (Table 1$)$.

Table 1. Accuracy values for three different concentrations of peptide $(n=3)$

\begin{tabular}{|c|c|c|c|}
\hline $\begin{array}{c}\text { Theoretical } \\
\text { Concentration, } \mu \mathrm{g} / \mathrm{mL}\end{array}$ & Area, mAu & $\begin{array}{c}\text { Practical } \\
\text { Concentration, } \mu g / \mathrm{mL}\end{array}$ & $\begin{array}{c}\% \\
\text { Recovery }\end{array}$ \\
\hline 25 & 567.98 & 24.87 & 99.48 \\
\hline 25 & 546.37 & 24.22 & 92.88 \\
\hline 25 & 544.13 & 24.01 & 96.04 \\
\hline \multicolumn{2}{|c|}{ Average } & 24.15 & 96.133 \\
\hline \multicolumn{2}{|c|}{$\%$ Bias } & 3.002 & \\
\hline 100 & 983.12 & 99.81 & 99.81 \\
\hline 100 & 993.55 & 99.23 & 99.23 \\
\hline 100 & 979.21 & 99.12 & 99.12 \\
\hline \multirow{2}{*}{\multicolumn{2}{|c|}{$\begin{array}{l}\text { Average } \\
\% \text { Bias }\end{array}$}} & 99.38 & 99.386 \\
\hline & & 0.233 & \\
\hline 200 & 1581.503 & 198.65 & 99.32 \\
\hline 200 & 1588.627 & 197.87 & 98.93 \\
\hline 200 & 1589.888 & 198.65 & 99.32 \\
\hline \multirow{2}{*}{\multicolumn{2}{|c|}{ Average }} & 198.39 & 99.195 \\
\hline & & 0.654 & \\
\hline
\end{tabular}




\section{Precision}

The precision structure was evaluated in stipulations of repeatability and reproducibility. For injection repeatability, six analyses of one concentration were performed in the same sample. For system repeatability and reproducibility, analyses of six diverse samples of one concentration were performed in the same day and 2 different days (Table 2). All CV values were found to be lower than $2 \%$.

Table 2. Injection repeatability values $(n=6)$

\begin{tabular}{ccccc}
\hline $\begin{array}{c}\text { Theoretical } \\
\text { concentration, } \mu \mathrm{g} / \mathrm{mL}\end{array}$ & $\begin{array}{c}\text { Area } \\
\mathrm{mAu}\end{array}$ & $\begin{array}{c}\text { Practical } \\
\text { concentration, } \mu \mathrm{g} / \mathrm{mL}\end{array}$ & $\begin{array}{c}\text { Area } \\
\mathrm{mAu}\end{array}$ & $\begin{array}{c}\text { Practical } \\
\text { concentration, } \mu \mathrm{g} / \mathrm{mL}\end{array}$ \\
\hline 200 & 1588.627 & 198.87 & 1926.66 & 210.77 \\
200 & 1589.888 & 196.56 & 1996.21 & 210.66 \\
200 & 1592.827 & 189.55 & 1543.33 & 189.87 \\
200 & 1583.432 & 199.10 & 1576.55 & 198.90 \\
200 & 1599.922 & 187.90 & 1675.23 & 197.78 \\
200 & 1600.974 & 191.32 & 1565.87 & 196.99 \\
Average & 1592.6116 & 193.883 & 1713.98 & 200.828 \\
Theoretical & 199.98 & & 200.65 & \\
concentration & & & $\mathrm{SD}$ & 4.90701 \\
& $\mathrm{SD}$ & 8.28646 & $\mathrm{CV}$ & 0.122 \\
\hline
\end{tabular}

Table 3. Linearity parameters of the analytical method

\begin{tabular}{cc}
\hline Parameters & Values \\
\hline Linearity Range & $5-35 \mu \mathrm{g} / \mathrm{mL}$ \\
Slope & 15.181 \\
Intercept & -1.506 \\
LOD & $5,65 \mu \mathrm{g} / \mathrm{mL}$ \\
LOQ & $17.1322 \mu \mathrm{g} / \mathrm{mL}$ \\
\hline
\end{tabular}

\section{Sensitivity}

Sensitivity was calculated based on the residual standard deviation (RSD) of the retort and the slope. Average values of six calibration curves were used for this purpose. By this method LOD was found as 5,65 $\mu \mathrm{g} / \mathrm{mL}$ and LOQ was found as $17.1322 \mu \mathrm{g} / \mathrm{mL}$ using the following equations, respectively.

$$
\begin{aligned}
& \mathrm{LOD}=4.1(\mathrm{SD} / \mathrm{Slope}) \text { Equation } 1 \\
& \mathrm{LOQ}=10(\mathrm{SD} / \mathrm{Slope}) \text { Equation } 2
\end{aligned}
$$

\section{Linearity}

The HPLC chromatogram of the peptide could be seen in Figure 1. The retention time $\left(t_{R}\right)$ was $13.99517 \mathrm{~min}$ at $220 \mathrm{~nm}$. The Mobile phase A 1\%w/v of triflouro acetic acid in water and mobile phase B $0.1 \% \mathrm{w} / \mathrm{v}$ of triflouro acetic acid in 80:20 ratio of acetonitrile and water solvent system. The calibration curve was prepared from five sample concentrations within the range of 5-35 $\mu \mathrm{g} / \mathrm{mL}$ (Figure 1) and found linear in this range. There were seven series of samples prepared and average values were used to prepare the calibration curve. The $\mathrm{r}^{2}$ value was found as 0.926 (Figure 2). 


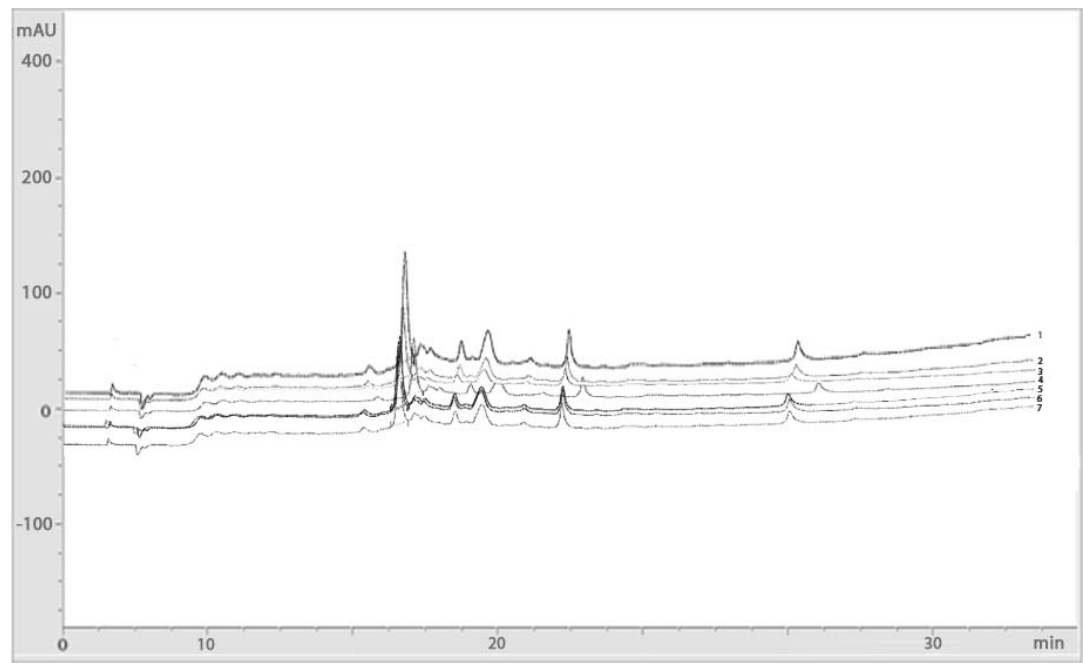

Figure 1. RP-HPLC chromatogram of $p$-ACC1 in different concentrations $(5-35 \mu \mathrm{g} / \mathrm{mL})$

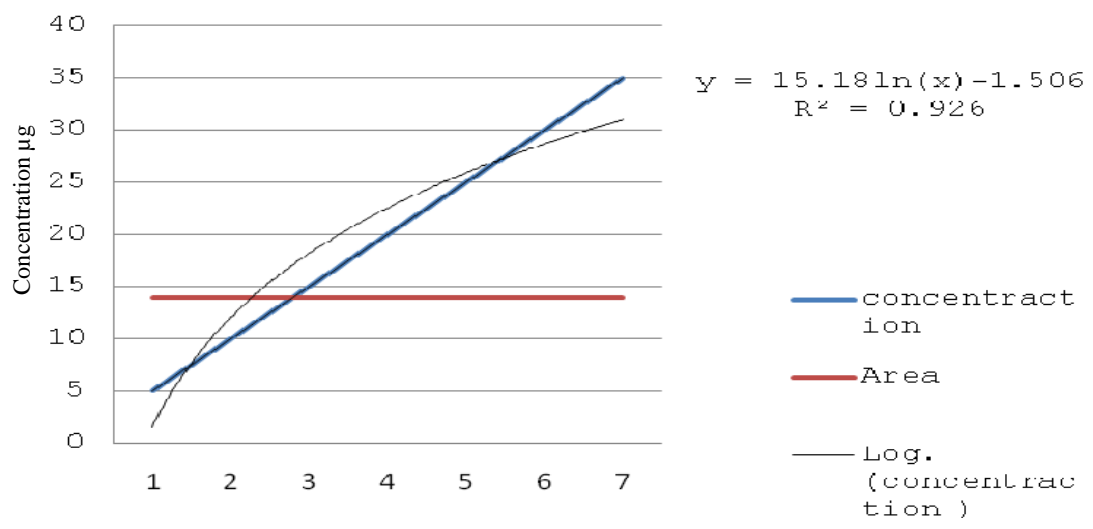

Figure 2. Calibration curves

Peak description [min]:

Signal: DAD1 B, Sig=220,4 Ref $=$ off

RetTime: $13.99517 \mathrm{k}$ :

Height: 115.15367 Area:

Start: $\quad 13.70362$ End:

Skew: $\quad 0.38946$ Excess:

width at half height:

5 sigma:

tangent:

tailing:

symmetry:

USP Tailing:

Integration type:

Time increment [msec]:

Data points:
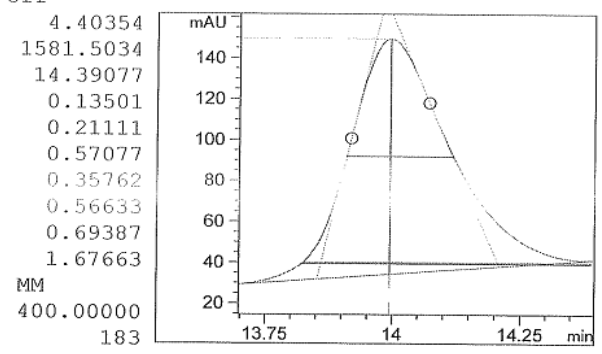

Statistical moments (BB peak detection):

MO: $\quad 1576.220569$

M1: $\quad 14.022289$

M2: $\quad 0.009562$

0.009562

Tangent method:

Efficiency: Plates per. .

column

24497

Halfwidth method:

24341
15026

5 sigma method:

20563

M4: $\quad 0.000287$

Statistical:

meter

97362

60106

Figure 3. Peak descriptions 


\section{System suitability}

Inject reference solution and ensure column efficiency not less than 2000 theoretical plates, the tailing factor is not more than 2.0 and \% of relative standard deviation of replicate injections of reference solution is not more than 2.0.

\section{Results and Discussion}

The next generation cancer therapy will be purely depends on the peptides. Within just a few years, the pipeline of therapeutic peptides has grown significantly. In 2004, there were 400 peptides in development globally; almost three times as many as in 2001. While the current pipeline is still primarily driven by early-stage projects (discovery/preclinical stages), an increasing number of peptides are maturing into later stage trials and reaching the market ${ }^{3-5}$. The majority of peptides currently in the market are generics with relatively low growth potential due to several inherent limitations like: peptides generally suffer from low stability (quick degradation and clearance from the body); low oral bioavailability (injection required); difficulties in delivery (cross-membrane transportation); risk of immunogenic effects; as well as challenging and costly synthesis (solubility issues) and so on $^{6}$. For overcome the above the issues, we require to formulate the peptide in to targeted drug delivery by itself or conjugation to another drug / drug carrier system ${ }^{5}$. However, there has not been an analytical method reported in the literature for this peptide. Thus, a RP-HPLC method has been developed and validated for the quantitative analysis of p-ACC1 in the present study.

\section{Conclusion}

The peptide which was taken in to the study has vital function for upcoming therapy of anti cancer chemotherapy. The peptide can be loaded with carrier and antibody labeled drug delivery system. In this study, a suitable RP-HPLC method was successfully developed and validated for the quantitative analysis.

\section{Reference}

1. Yu X, Chini C.C, He M and Mer G and Chen J, Science, 2003, 302(5645), 639-642. DOI:10.1126/science.1088753

2. ICH Harmonised Tripartite Guideline.Validation of Analytical Procedures: Text and Methodology Q2 (R1), 2005.

3. Rao Y N, Sudhir Gupta and Agarwal S P, National Cancer Control Programme: Current Status \& Strategies. 50 Years of Cancer Control in India, 2002, 41-47.

4. McGlynn K.A, Tsao L, Hsing A W, Devesa S S and Fraumeni J F, Int J Can., 2001, 94(2), 290-296; DOI:10.1002/ijc.1456

5. El-Serag H B, Gastroenterology, 2004, 127(5), S27-S34; 10.1053/j.gastro.2004.09.013

6. Jagatheesh K and Elangovan N, J Pharm Sci Innov., 2013, 2(5), 4-8;

DOI: $10.7897 / 2277-4572.02576$ 